\title{
Online Science Learning Implementation During the Covid-19 Pandemic at SMP N 1 Singorojo
}

\author{
Ardhya Handayani ${ }^{1, *}$ Amat Jaedun ${ }^{2}$ Ernita Apriani ${ }^{3}$ \\ ${ }^{1}$ Master of Educational Research and Evaluation, Graduate School, Universitas Negeri Yogyakarta, Indonesia \\ ${ }^{2}$ Department of Educational Research and Evaluation, Graduate School, Universitas Negeri Yogyakarta, \\ Indonesia \\ ${ }^{3}$ Master of Physics Education, Faculty of Mathematics and Natural Sciences, Universitas Negeri Yogyakarta, \\ Indonesia \\ *Corresponding author. Email: ardhyahandayani.2019@student.uny.ac.id
}

\begin{abstract}
The purpose of this research aims to analyse the implementation of online science learning during a pandemic in SMP N 1 Singorojo. This research is quantitative experimental research. The sample of this research consisted of 89 students of VII grade and a teacher. The sample was selected using a random sampling technique. Data collection in this research using a questionnaire for students and teachers. The result of this research shows that the implementation of online science learning in SMP N 1 Singorojo went well. However, several aspects need to be improved, that is the assignment discussion and feedback, accessibility, student engagement, and stakeholder support.
\end{abstract}

Keywords: Online learning, Science learning, Covid-19

\section{INTRODUCTION}

The spread of Covid-19 around the world, force World Health Organization (WHO) to set it to be a pandemic. UNESCO (United Nations Educational, Scientific, and Cultural Organization) on March 4, 2020, suggest learning activity be done with distance learning and open an educational platform that can be used to reach all of the student [1]. The enacted rule, Number 4, year 2020 regarding the implementation of education during the Covid-19 pandemic, lead to a change in the learning activity from direct learning (face to face) to online learning. One of the methods is using a webinar tutorial[2].

This change becomes a new challenge to the teachers, many teachers not familiar with online learning. At least 3 obstacles teachers face during online learning, there are pedagogy, technology, and communication [3]. Online learning itself is a learning activity that is implemented by leveraging the internet, technology, and communication managed using learning system management (LSM) [4,5].

Constraints experienced by students, teachers, and parents during online learning activity are mastery of technology, and the expense of the internet bills [6].
Moreover, from the parents' perspective, online learning makes them have extra works to accompanying children to learn. Another thing that must be noticed is communication and interaction between students, teachers, parents, and school $[7,8]$.

The online learning activity is different from offline learning, there are certain criteria in online learning. According to Academic Partnership, there are seven aspects as course overview and introduction, learning objective, assessment and measurement, instructional materials, learner interaction and engagement, course technology, learner support, accessibility. This aspect must be shown in online learning.

Online learning is implemented in all courses, one of them is a science lesson. Science learning is a learning activity that needs interaction to found facts, building concepts, and skills through the scientific process [9]. The scientific process needs activity for the students. This creates another obstacle for teachers in science online learning. It is necessary to analyze the implementation of online science learning during a pandemic. This is important because there is no time yet when the pandemic will end and the implementation of online learning has stopped. 


\section{RESEARCH METHOD}

This research is descriptive quantitative research and supported by teacher's statement. The sample of this research consisted of 89 students of VII grade and a teacher. The sample was selected using a random sampling technique. This research was held between April - May 2020, the beginning of the implementation of online learning. Data collection in this research using 2 instruments, a questionnaire for students, and an opened questionnaire for teachers. The instrument developed using qualification criteria from Academic Partnership, there are six criteria, that are learning objective, instructional materials, course technology, learner support, and accessibility. The construct validity of this instrument is 0,85 (KMO) and reliability 0,90 .

\section{RESULT AND ANALYSIS}

From the data collecting process, there is information about the learning process as learning objectives and materials, interaction, students' engagement, support, and technology that use, and accessibility. Besides that, there is information from the teacher about science learning in the covid-19 pandemic era. The information is about planning and science learning activity, technology use during the study from home, students' interaction, and support from the stakeholder.

\subsection{Science Learning Planning And Implementation}

The beginning of this part is discussing information from the teacher. From the teacher perspective, the planning (RPP) (before covid-19 pandemic) cannot be done. Teachers make changes from the actual plan. According to the teacher, approximately $40 \%$ of the actual plan was change. The discrepancy happened because the practical activity (in the laboratory) cannot be done. The teacher said that the practical activity being replaced by activity that can be done at home using simple tools that can be found at home.

From the student perspective, science learning implementation can be seen from the learning objective and learning materials. From the learning objective (code 1.1., 1.2, 1.3) shows that the teacher already tells students about learning materials. The student understands the learning objective, and the materials that are given correspond with the learning objective.

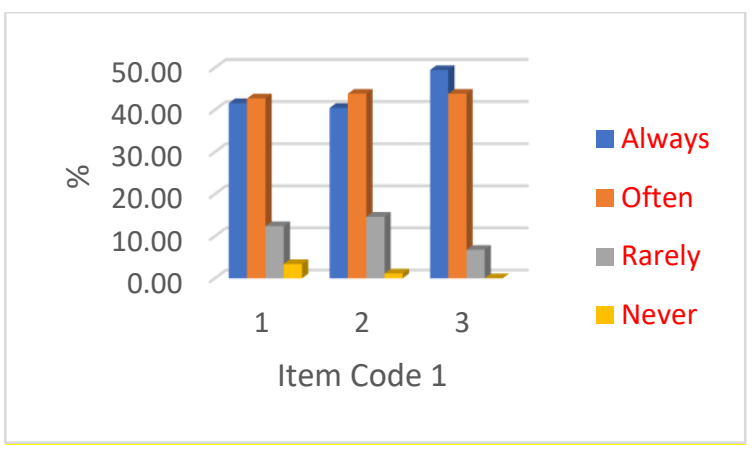

Figure 1 Students' understanding on the learning objective

Figure 1 shows that the majority of the student ( 40 - 50\%) know the learning objective in a science subject. Learning objective is an important part of learning implementation and attainment. Learning objective creates a student mindset and focuses on understanding the learning materials[10].

Instructional materials (code k2.1, k2.2, k2.3, k2.4, k2.5) show students already understand the material and activities they have to do. Figure 2 shows the majority of students choose scale 3 .

It implied that students understand and perform learning activities online. The understanding that the student has may happen because the teacher using the right media. It can be shown from the technological aspect. 0 students feel the media does not really compatible. The majority of student states that the teacher chose the right media for certain materials. Media can help the student understand the materials, so choosing the right learning media became an important factor that must be adjusted with the science materials' characteristics[11,12].

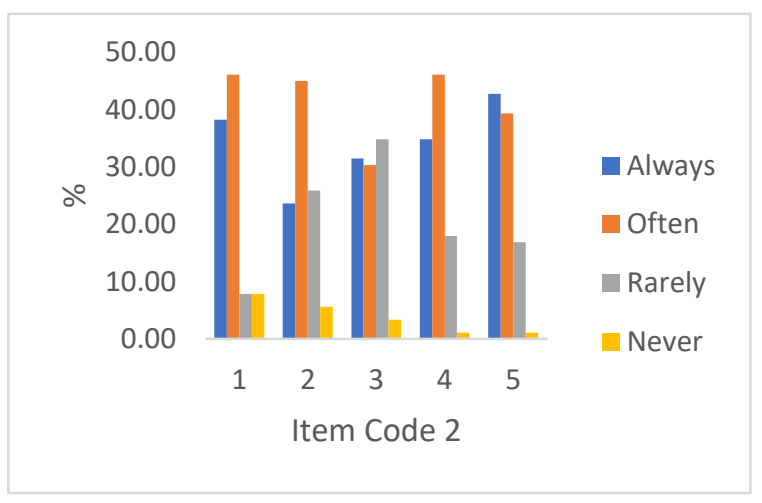

Figure 2 Student understanding on science material and learning activity 


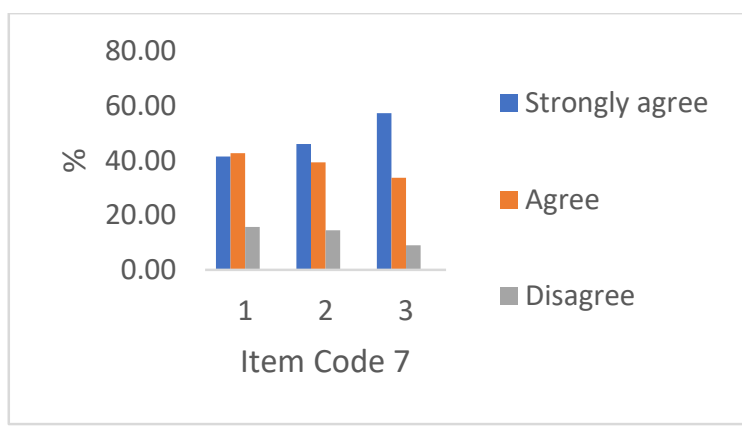

Figure 3 Reaction on the media used

\subsection{Stakeholders Interaction}

This part discusses about a) interaction between teacher and students (K5), b) learner engagement $(\mathrm{K} 4), \mathrm{c})$ learner support from parents and teacher (K6).

Item code 4, shows learner engagement. Learner engagement item's reveals students attitudes towards learning. The first item shows majority $(51,69 \%)$ students do the science learning activity, but later on, item 2, 3, 4, and 5, dominated with scale 3 and 2 . Those items covered the accuracy of collecting assignments, sourcebook used, and participation in a learning activity. It reflects their passions and seriousness in carrying out science learning. From this we know that although student do the learning activity but does not take the course seriously or having difficulty on doing theirs course.

Second, teacher and student relationship. The data show a good interaction between students and teachers. The result of learner interaction with teacher can be seen in Figure 5 Student interaction with teahcer. 5.1, 5.2, 5.3, 5.5. 5.6 items covered learner and teacher interaction regarding activity and assignment. Graph 5 discovered that teacher give a clear explanation about the activity and assignment. But in item number 5.4, 5.7, and 5.8 there is an increment scale 2 selection. This item is discovering teacher feedback and science learning schedule. It can be said that teacher gives a good response in the science learning activity and its assignment but lacks in giving feedback on the assignment.

This also supported by teacher's statement, that says few students does not collect their assignment on time. Besides that, teacher also state that they have difficulty in internet access dan time management. And makes them have difficulty on giving feedback that student needs immediately.

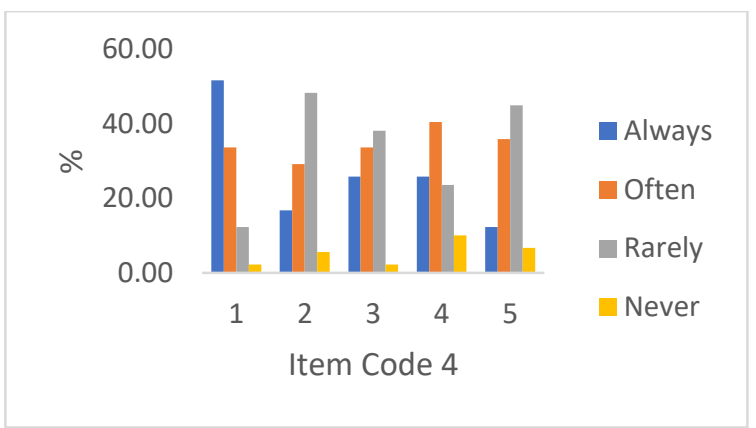

Figure 4 Learner engagement on online science learning

Student and teacher interaction is an important aspect of the learning process. Students and teacher interaction create a positives atmosphere during class [13]. Furthermore, research found a high correlation between teacher and students interact with family conditions and their socio-demographics [14].

With this information, the relationship between student seriousness in carrying out the learning (collecting assignment) in online learning with teacher feedback need to be studied more.

Another aspect to discuss is learner support besides the teacher. This part shows parents' support in the learning activity during the covid-19 pandemic from the students' perspective.

There are 3 items in this part. The first item asking about parents' support, the data shows the majority of parents $(48,31 \%)$ give a good amount of support. On the other hand, $19,10 \%$ of students feel parents never give attention or supports during online learning. This finding needs to explore more, whether the parents truly do not care or they do not understand the learning materials.

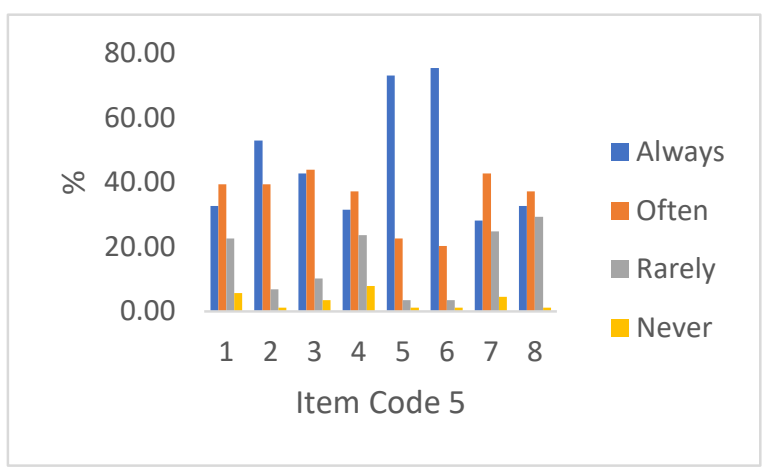

Figure 5 Student interaction with teacher 


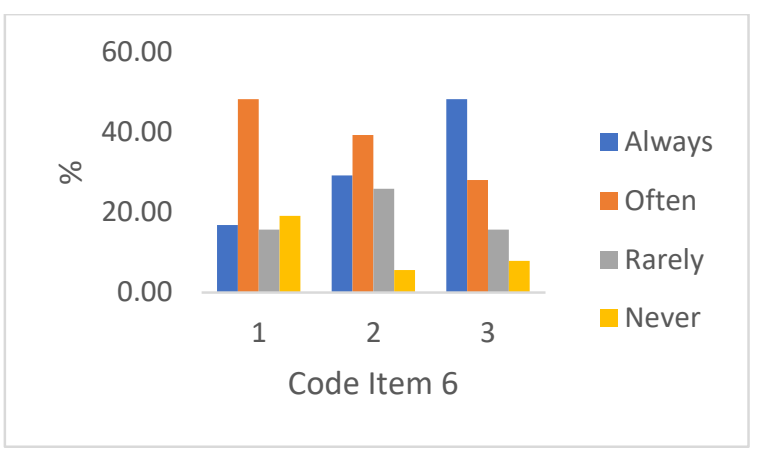

Figure 6 Family support

Item 6.2 discovering students' distraction during science online learning. The data show the majority feels distracted by their home atmosphere during science online learning. Furthermore, the majority of students (49\%) felt teachers give too much homework, and it make their study harder.

\subsection{Accessibility}

Item Code 3 shows students' accessibility to science online learning. Item 3.1. show the majority of the students can access the media, but some of them $(26,97 \%$ and $3,37 \%)$ still have difficulty to access the media selected by the teachers. Moreover, some students do not have good internet access. Approximately $13,5 \%$ of students state they cannot access the internet.

Access is an important part of online learning. Without the internet, the science learning process during the covid-19 cannot be done. This finding becomes a critical problem because it shows that few students cannot follow the learning activity well.

\subsection{Science Online Learning Implementation Constrain}

The difficulty during online learning activity is internet and application access used in the online learning activity. This thing happened not only to students but also teacher, that makes them has a hard time to monitor students' activity.

Not only that, but bad internet access also making assignments untimely submitted. From a teacher's perspective, they must pay extra attention to science learning materials that are more suitable to use practicum. The data show there is a lack of support from stakeholders like parents and the government.

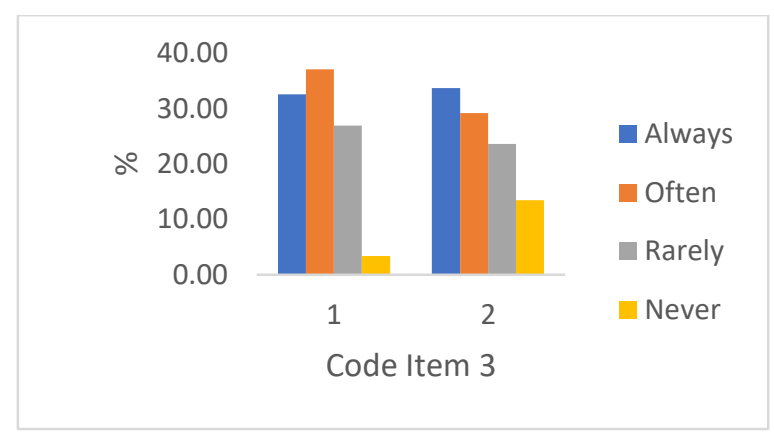

Figure 7 Student accessibility on science online learning

\section{CONCLUSION}

From this study, it can be concluded that the implementation of science online learning during the covid-19 pandemic in SMP N 1 Singorojo went well, especially in the learning materials, teacher and student interaction, and assignment aspect. However, several aspects need to be improved, that is the assignment discussion and feedback, accessibility, student engagement, and stakeholder support.

\section{REFERENCES}

[1] UNESCO, COVID-19 Educational Disruption and Response, UNESCO, Mar. 2020. Accessed on: Jul. 5, 2020. [Online]. Available: https://en.unesco.org/news/covid-19educational-disruption-and-response

[2] D. Ratu, A. Uswatun, H. Pramudibyanto, Pendidikan dalam Masa Pandemi Covid-19, Jurnal Sinestesia 10(1) (2020) 41-48.

[3] N. Nurkolis, M. Muhdi, Keefektivan Kebijakan E-Learning Berbasis Sosial Media pada PAUD di Masa Pandemi Covid-19, Jurnal Obsesi: Jurnal Pendidikan Anak Usia Dini 5(1) (2020) 212. DOI: https://doi.org/10.31004/obsesi.v5i1.535

[4] Centre for Educational Research and Innovation OECD, E-learning in Tertiary Education: Where Do We Stand, OECD, 2005. DOI: https://doi.org/10.1787/9789264009219-en

[5] A. Sangra, D. Vlachopoulos, N. Cabrera, Building An Inclusive Definition of E-Learning: An Approach to The Conceptual Framework, International Review of Research in Open and Distance Learning 13 (2012) 145-159. DOI: https://doi.org/10.19173/irrodl.v13i2.1161

[6] F. Firman, S. Rahayu, Pembelajaran Online di Tengah Pandemi Covid-19, Indonesian Journal 
of Educational Science 2(2) (2020) 81-89. DOI: https://doi.org/10.31605/ijes.v2i2.659

[7] A. Purwanto, et al., Studi Eksploratif Dampak Pandemi COVID-19 Terhadap Proses, Pembelajaran Online di Sekolah Dasar, EduPsyCouns: Journal of Education, Psychology and Counseling 2(1) (2020) 1-12.

[8] L.D. Herliandry, M.E. Suban, Pembelajaran pada Masa Pandemi Covid-19, Jurnal Teknologi Pendidikan 22(1) (2020) 65-70. DOI: https://doi.org/10.21009/jtp.v22i1.15286

[9] I. Wilujeng, I.G.P. Suryadarma, The effectiveness of integrating local potential on science process skills and conceptual understanding, in: Proceedings of the International Conference on Learning Innovation, vol. 164, Atlantis Press, Amsterdam, 2018, pp. 17-21. DOI: https://doi.org/10.2991/icli-17.2018

[10] K.M.W. Mitchell, W.R. Manzo, The Purpose and Perception of Learning Objectives, Journal of Political Science Education 14(4) (2018) 456472.

DOI: https://doi.org/10.1080/15512169.2018.1433542

[11] Preeti, Education and Role of Media in Education System, International Journal of Scientific Engineering and Research 2(3) (2014) 174-175.

[12] T.C. Reeves, The Impact of Media And Technology in Schools: A Research Report Prepared for The Bertelsmann Foundation, The University of Georgia, 1998.

[13] L.C.A. Claessens, et al., Positive TeacherStudent Relationships Go Beyond The Classroom, Problematic Ones Stay Inside, Journal of Educational Research 110(5) (2017) $478-493$.

DOI: https://doi.org/10.1080/00220671.2015.1129595

[14] F.H.K. Wanders, A.B. Dijkstra, R. Maslowski, I. van der Veen, The Effect of Teacher-Student and Student-Student Relationships on The Societal Involvement of Students, Research Papers in Education 35(3) (2019) 266-286. DOI: https://doi.org/10.1080/02671522.2019.1568529 